QUALITY

Volume 7, Nomor 2, 2019: 48 - 63

\title{
PERAN KEPALA SEKOLAH DALAM MENINGKATKAN MANAJEMEN MUTU PENDIDIKAN DI MADRASAH IBTIDAIYAH
}

\author{
Anik Muflihah \\ IAIN Kudus, Kudus, Indonesia \\ anik.muflihah88@gmail.com \\ Arghob Khofya Haqiqi \\ IAIN Kudus, Kudus, Indonesia \\ arghobhaqiqi@stainkudus.ac.id
}

\begin{abstract}
Abstrak
Penelitian ini bertujuan untuk mengetahui dan mendeskripsikan mengenai peran kepala sekolah dalam meningkatkan manajemen mutu pendidikan di MI NU Raudlatut Tholibin Jepangpakis Jati Kudus. Metode penelitian yang digunakan dalam penelitian ini yaitu penelitian kualitatif deskriptif dengan menggunakan teknik observasi dan juga wawancara terhadap kepala sekolah tempat penelitian. Hasil yang diperoleh menjelaskan bahwa kepala sekolah telah melaksanakan berbagai upaya dan telah berperan untuk meningkatkan manajemen mutu pendidikan di MI NU Raudlatut Tholibin. Upaya yang dilakukan meliputi berbagai peran penting dalam hal kepemimpinan dan juga pengelolaan madrasah baik terhadap guru, siswa, sarana prasarana dan juga pendukung sekolah lainnya. Kesimpulan dalam penelitian ini peran kepala sekolah sangat penting dalam meningkatkan manajemen mutu pendidikan dan peran kepala sekolah telah di lakukan dalam peran sebagai edukator, manajer, administrator, supervisor, leader, inovator dan juga motivator.
\end{abstract}

Kata Kunci: Kepala Sekolah, Manajemen mutu, Madrasah Ibtidaiyah

\begin{abstract}
This study aims to study and describe the role of school principals in improving education management in MI NU Raudlatut Tholibin Japanpakis Jati Kudus. The research method used in this study is descriptive qualitative research using observation techniques and also interviews with the principal of the research location. The results obtained explained that the principal had made various efforts and had improved to support the management of education in MI NU Raudlatut Tholibin. Efforts made related to the important role in terms of leadership and management of madrasas both for teachers, students, facilities and other school supporters. The conclusion in this study is that the role of the principal is very important in improving education management and the role of the principal must be carried out in the role of educators, managers, administrators, supervisors, leaders, innovators and motivators.
\end{abstract}

Keywords: School Principal, Quality management, Madrasah Ibtidaiyah 


\section{A. Pendahuluan}

Salah satu agenda reformasi di bidang pendidikan seperti pendelegasian kewenangan pengelolaan pendidikan pada pemerintah daerah, sebagaimana UU No. 23 tahun 2014. UU tersebut menyebut bahwa yang akan menjadi kewenangan pemerintah daerah tidak sepenuhnya yaitu terbatas pada aspek pembiayaan, sumber daya manusia dan sarana-prasarana. Sementara untuk aspek-aspek menyangkut kurikulum, pembelajaran, evaluasi dan pengukuran, sarana dan alat pembelajaran, metode dan waktu belajar, buku serta alokasi belanja dan penggunaan anggaran, semuanya menjadi kewenangan sekolah. Oleh karena itu kepala sekolah dan para guru dituntut bertanggung jawab terhadap kualitas proses dan hasil belajar guna meningkatkan mutu pendidikan secara nasional (Rosyada, 2013).

Mengacu pada UU yang direvisi sebanyak tiga kali dari tahun 1999, 2004, dan 2014 menunjukkan bahwa era reformasi pendidikan yang sangat monumental dalam sejarah pendidikan di Negara Republik Indonesia ini, dimana otoritas yang sangat besar diberikan langsung pada sekolah. Sekolah bisa mengembangkan inovasinya masing-masing dalam mengembangkan perlakuan pada siswa dalam belajar, bahkan sekolah diberi kewenangan untuk menetapkan kebijakan tersendiri, misalkan saja disekolah apakah akan fullday school atau partday school dalam penggunaan waktu belajar. Selain itu, apakah sekolah akan menyusun sendiri buku teks yang diajarkan sesuai dengan kurikulum yang disepakati, atau membeli buku-buku karya guru lainnya, ini semua menjadi kewenangan sekolah dalam hal pengelolaan atau manajemen untuk meningkatkan mutu pendidikan pada sekolah tersebut.

Manajemen dapat diartikan sebagai seuah proses pengelolaan atau pengaturan dalam suatu hal untuk mencapai tujuan tertentu. Sedangkan manajemen pendidikan menurut sagala (2005) dijelaskan sebagai usaha serta upaya pengelolaan yang diterapkan dalam dunia pendidikan, meliputi pembinaan, pengembangan, pengendalian usaha dan praktik dalam pendidikan untuk mencapai tujuan pendidikan secara efektif dan efisien. Manajemen pendidikan juga diartikan menurut Mulyasa (2002) sebagai suatu proses kerjasama yang dilakukan secara sistematis, sistematis, terstruktur serta komprehensif untuk mewujudkan tujuan pendidikan nasional yang telah ditetapkan baik tujuan jangka pendek, menengah maupun tujuan jangka panjang. 
Proses manajemen dalam rangka mewujudkan peningkatan kualitas disebut juga sebagai manajemen mutu pendidikan. Dalam hal ini manajemen yang dilakukan haruslah sudah mempunyai kaidah kaidah ataupun aturan agar kualitas dari pendidikan dilembaga pendidikan betul betul dapat meningkat. Salah satu faktor yang paling penting dalam menopang dan melaksanakan manajemen mutu pendidikan ini tidak lain yaitu kepala sekolah ataupun kepala madrasah pada lembaga pendidikan tersebut.

Namun sekarang ini implementasi dari adanya manajemen mutu pendidikan di sekolah ataupun madrasah belum berjalan dengan baik. Penyebab belum tercapainya manajemen mutu pendidikan yang baik disebabkan programnya kurang baik atau kurang tepat, program tidak dilaksanakan dengan baik, atau prasyaratbelum dipenuhi juga dengan baik. Selain itu, Sidi (2005) mengemukakan bahwa telah diupayakan beberapa strategi pembangunan pendidikan nasional untuk mewujudkan mutu pendidikan antara lain yaitu:

1) Menerapkan kegiatan perencanaan berbasis kompetensi lokal,

2) Meningkatkan pemerataan kualitas pendidikan,

3) Menetapkan system pengembangan manajemen mutu secara menyeluruh,

4) Meriview kurikulum secara pereodik dan mengembangkan implementasi kurikulum secara berkesinambungan,

5) Merancang proses penerapan pendekatan dan metode serta isi pendidikan

6) Meningkatkan system manajemen sumber pendidikan yang lebih adil dan juga memadai serta mendayagunakan dan memobilisasi sumber dana secara efisien,

7) Membuat rambu-rambu kebijakan pengembangan program pendidikan yang luwes,

8) Menyusun peraturan perundangan yang mengatur perimbangan peran pemerintah serta non pemerintah dalam pendidikan secara komprehensif dan,

9) Memangkas unit birokrasi yang dipandang kurang bermanfaat.

Kepala sekolah merupakan orang yang profesional dalam organisasi sekolah yang bertugas mengatur semua sumber organisasi dan bekerjasama dengan guru-guru dalam mendidik siswa untuk mencapai tujuan pendidikan. Dengan keprofesionalan 
kepala sekolah ini, pengembangan profesionalisme tenaga kependidikan mudah dilakukan karena sesuai dengan fungsinya, kepala sekolah memahami kebutuhan sekolah yang ia pimpin sehingga kompetensi guru tidak hanya terbatas pada kompetensi yang ia miliki sebelumnya, melainkan bertambah dan berkembang dengan baik sehingga profesionalisme guru akan terwujud

Peran kepala sekolah sangat menopang keberhasilan suatu lembaga pendidikan formal, namun di pihak lain untuk mencari pemimpin ini bukan hanya menjadi masalah bagi dunia usaha, akan tetapi juga merupakan masalah dunia pendidikan. Lembaga pendidikan Islam, kepemimpinan diperankan oleh seorang kepala sekolah yang sekaligus bertindak sebagai seorang pendidik yang bertanggungjawab terhadap kemajuan sekolah.

Demikian halnya pada MI NU Raudlatut Tholibin tidak terlepas dari peran kepala sekolah sebagai pemimpin sekolah tersebut. Pola-pola kepemimpinan yang digunakan oleh kepala sekolah dalam mengelola sekolah ini terbukti memberikan kontribusi atau sumbangan yang positif bagi perkembangan dan kemajuan di kemudian hari.

MI NU Raudlatut Tholibin merupakan sekolah yang telah berdiri sejak tahun 1982, selama itu telah terjadi 6 kali pergantian kepala sekolah. Letak sekolah yang berada di desa Jepangpakis Kecamatan Jati Kabupaten Kudus ini dengan kapasitas siswa berasal dari golongan menengah ke bawah yang sangat membutuhkan perhatian khusus agar pembelajarannya dapat berjalan dengan baik.

Kualifikasi peran kepala sekolah dapat dirumuskan secara lebih jelas setelah dilakukan penelitian yang lebih mendalam terhadap aktivitas kepala sekolah sebagai pemimpin sebagai pemimpin formal yang bertanggungjawab atas kelangsungan hidup sekolah khususnya yang berkaitan dengan upaya pengembangan dan kemajuan sekolah tersebut.

Banyak faktor penghambat tercapainya kualitas kepemimpinan seorang kepala sekolah seperti proses pengangkatannya tidak transparan, rendahnya mental kepala sekolah yang ditandai dengan kurangnya motivasi dan semangat serta kurangnya disiplin dalam melakukan tugas dan seringnya datang terlambat, wawasan kepala sekolah yang masih sempit serta banyak faktor lain yang menghambat kinerja seorang kepala sekolah untuk meningkatkan kualitas pendidikan pada lembaga yang 
dipimpinnya. Ini mengimplikasikan rendahnya produktivitas kerja kepala sekolah yang berimplikasi juga pada mutu. Senada dengan hasil penelitian Sri, Yusrizal, \& Nasir (2016) salah satu kendala dalam meningkatkan mutu pendidikan adalah kepala sekolah yang kurang tepat waktu dalam melaksanakan program peningkatan mutu.

Dalam melaksanakan fungsi kepe-mimpinannya, kepala sekolah harus melakukan pengelolaan dan pembinaan terhadap seluruh komponen sekolah melalui kegiatan administrasi, manajemen dan kepemimpinan yang sangat tergantung pada kemampuan manajerial seorang kepala sekolah. Hasil penelitian dari Busrin, Aunurrahman, \& Aswandi (2014) menunjukkan bahwa terdapat hubungan yang signifikan antara supervisi pengawas dan kemampuan manajerial kepala sekolah secara bersama-sama dengan kinerja guru. Berdasarkan pada latar belakang diatas maka permasalahan yang akan dibahas adalah bagaimana peran kepala sekolah dalam meningkatkan manajemen mutu pendidikan di MI NU Raudlatut Tholibin.

\section{B. Pembahasan}

\section{Pengertian Kepala Sekolah}

Sekolah merupakan sebuah lembaga yang bersifat kompleks serta unik. Dikatakan bersifat kompleks karena sekolah sebagai organisasi di dalamnya terdapat berbagai dimensi serta aspek yang satu dengan yang lain saling berkaitan dan saling menentukan. Sedangkan sifat unik, menunjukkan bahwa sekolah sebagai organisasi memiliki ciri-ciri tertentu yang tidak dimiliki oleh organisasi-organisasi atau lembaga lain. Ciri-ciri yang menempatkan sekolah memiliki karakteristik tersendiri, dimana terjadi proses belajar mengajar, tempat terselenggaranya pembudayaan kehidupan umat manusia (Wahjosumidjo, 2002). Karena sifatnya yang kompleks dan unik itulah sehingga sekolah sebagai organisasi memerlukan tingkat koordinasi yang tinggi.

Keberhasilan sekolah merupakan keberhasilan kepala sekolah. Kepala sekolah berasal dari dua kata yaitu Kepala dan Sekolah. Kata Kepala mempunyai arti ketua atau pemimpin dalam suatu organisasi atau sebuah lembaga. Sedangkan Sekolah dapat diartikan sebagai sebuah lembaga dimana menjadi tempat menerima dan memberi pelajaran (Wahjosumidjo, 2002). Dengan demikian secara sederhana kepala sekolah dapat dijelaskan sebagai seorang tenaga profesional guru yang diberi tugas untuk memimpin suatu 
sekolah dimana diselenggarakan proses belajar mengajar, atau tempat dimana terjadi interaksi antara guru yang memberi serta siswa menerima pelajaran. Kata memimpin dari rumusan tersebut mengandung makna luas, yaitu kemampuan untuk menggerakkan segala sumber yang ada pada suatu sekolah sehingga dapat didayagunakan secara maksimal untuk mencapai tujuan yang telah ditetapkan (Wahjosumidjo, 2002).

Adapun kewenangan kepala sekolah sebagai pemimpin untuk mencapai tujuan sekolah adalah mengatur dan mengelola tiga hal pokok, yaitu personil, sarana dan dana. Sebagai seorang manager, kepala sekolah harus mampu dan mempunyai kemampuan manajemen yang memadai untuk menjalankan tugasnya. Kemampuan ini sangat mendukung pada saat mengatur personil atau SDM yang dimiliki sekolah (Saroni, 2006). Kepala sekolah adalah sosok yang diberikepercayaan dan kewenangan oleh banyak orang (anak buah) untuk membawa sekolah ke arah tujuan yang ingin dicapai. Kepercayaan yang diberikan oleh anak buah ini adalah didasarkan pada beberapa aspek yang dimiliki oleh kepala sekolah dan diharapkan dapat menjadi modal untuk membawa pada keberhasilan bersama (Saroni, 2006). Kepala sekolah juga merupakan jabatan pemimpin yang tidak bisa diisi oleh orang-orang tanpa didasarkan atas pertimbangan-pertimbangan. Siapapun yang akan diangkat menjadi kepala sekolah harus ditentukan melalui prosedur-prosedur tertentu (Wahjosumidjo, 2002). Sebagai seorang pemimpin, kepala sekolah mempunyai pengaruh yang dominan dalam meningkatkan mutu hasil belajar, dan merupakan orang yang bertanggung jawab terhadap keberhasilan sekolah yang dipimpinnya dalam mencapai tujuan pendidikan. William menyatakan "The leader behavior of school principal is one determinant of the ability of a school to attain its stated eduacational goals". Pendapat tersebut menggambarkan bahwa setiap perilaku kepala sekolah sebagai pemimpin pendidikan diarahkan untuk membantu pencapaian tujuan pendidikan, sehingga kepala sekolah berkewajiban dalam membina, mengarahkan, menugasi, memeriksa, mengukur hasil kerja para guru di sekolah yang dipimpinnya (Mujtahid, 2011). Berdasarkan penjelasan di atas maka dapat disimpulkan bahwa kepala sekolah atau madrasah merupakan 
seorang tenaga profesional guru yang dipercaya memimpin sekolah dan elemenelemennya untuk mencapai mutu dan tujuan pendidikan.

\section{Peran Kepala Sekolah dalam Meningkatkan Mutu Pendidikan}

Peranan kepala sekolah dalam rangka meningkatkan mutu pendidikan sangat penting karena dapat mempengaruhi berhasil dan tidaknya mutu pendidikan itu sendiri. Secara garis besar, ruang lingkup tugas kepala sekolah dapat diklasifikasikan ke dalam dua aspek pokok, yaitu pekerjaan di bidang administrasi sekolah dan pekerjaan yang berkenaan dengan pembinaan profesional kependidikan.

Dalam bidang pendidikan, yang dimaksud dengan mutu memiliki pengertian sesuai dengan makna yang terkandung dalam siklus pembelajaran.Secara ringkas dapat disebutkan beberapa kata kunci pengertian mutu, yaitu: sesuai standar, sesuai penggunaan pasar/ pelanggan, sesuai perkembangan kebutuhan, dan sesuai lingkungan globa. Adapun yang dimaksud mutu sesuai dengan standar, yaitu jika salah satu aspek dalam pengelolaan pendidikan itu sesuai dengan standar yang telah ditetapkan.

Dalam pandangan masyarakat umum sering dijumpai bahwa mutu sekolah dapat di tinjau dari ukuran gedung yang mewah. Ada pula masyarakat yang berpendapat bahwa kualitas sekolah dapat dilihat dari jumlah lulusan sekolah tersebut yang diterima di jenjang pendidikan selanjutnya. Untuk dapat memahami kualitas pendidikan formal di sekolah, perlu kiranya melihat pendidikan formal di sekolah sebagai suatu sistem. Selanjutnya mutu sistem tergantung pada mutu komponen yang membentuk sistem, serta proses yang berlangsung hingga membuahkan hasil.

Dalam pelaksanaan manajemen peningkatan mutu, kepala sekolah harus senantiasa memahami sekolah sebagai suatu sistem organisasi. Kepala sekolah dalam membangun sumber daya manusia melalui manajemen personalia (Suwardi, 2014). Secara umum Slamet (2000) menjelaskan karakteristik kepala sekolah tangguh, yaitu:

a) Memiliki wawasan jauh kedepan dan tahu tindakan apa yang harus dilakukan serta paham benar tentang cara yang akan ditempuh; 
b) Memiliki kemampuan mengkoordinasikan dan menyerasikan seluruh sumberdaya terbatas yang ada;

c) Memiliki kemampuan mengambil keputusan, memobilisasi sumberdaya yang ada, toleransi terhadap perbedaan, dan

d) Memiliki kemampuan memerangi musuh-musuh kepala sekolah, yaitu ketidakpedulian, kecurigaan, tidak membuat keputusan, mediokrasi, imitasi, arogansi, pemborosan, kaku, dan bermuka dua dalam bersikap dan bertindak.

Adapun peran kepala sekolah dalam meningkatkan mutu pendidikan, yang meliputi perannnya yakni sebagai edukator, manajer, administrator, supervisor, leader, inovator, serta motivator (Mulyasa, 2003; Vivi, 2013).

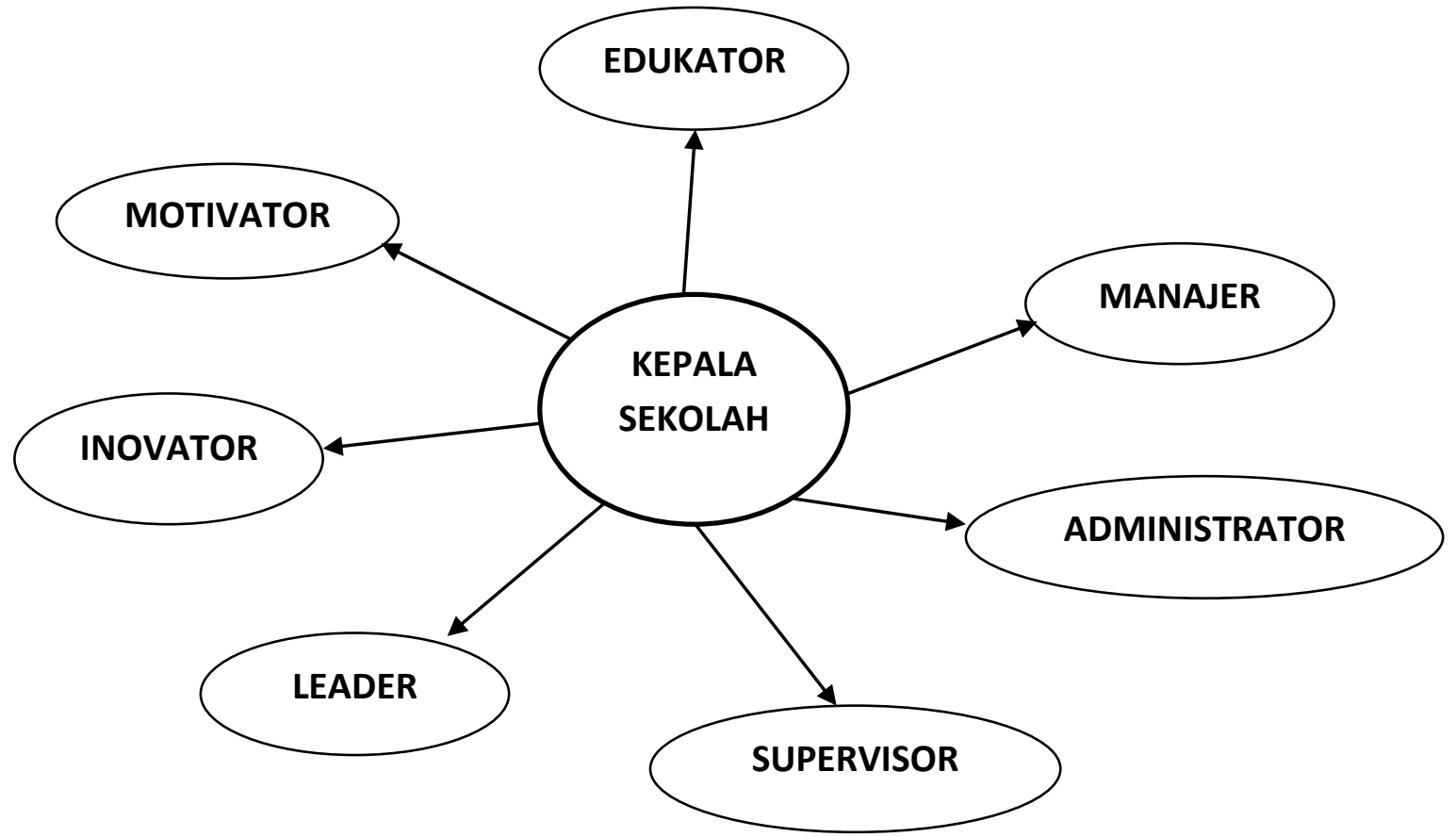

Gambar 1. Diagram peran kepala sekolah dalam meningkatkan mutu pendidikan

a) Kepala sekolah sebagai edukator, kepala sekolah bertugas untuk membimbing guru, tenaga kependidikan, siswa, mengikuti perkembangan iptek, dan memberi teladan yang baik.Seperti pemaparan dari Vivi (2013) 
bahwa untuk menciptakan iklim sekolah yang kondusif diperlukan kerjasama atau hubungan yang harmonis antara seluruh warga sekolah dan tidak hanya menjadi tanggung jawab kepala sekolah semata. Oleh karena itu upaya yang dapat dilakukan kepala sekolah dalam meningkatkan kinerjanya sebagai edukator, khususnya dalam peningkatan kinerja tenaga kependidikan dan prestasi belajar peserta didik adalah mengikutsertakan guru-guru dalam pendidikan lanjutan dengan cara mendorong para guru untuk memulai kreatif dan berprestasi.

b) Kepala sekolah sebagai manajer, mempunyai fungsi:menyusun perencanaan, mengkoordinasikan kegiatan, melakukan pengawasan, melakukan evaluasi terhadap kegiatan, mengadakan rapat, mengambil keputusan, mengatur proses pembelajaran, mengatur administrasi, dan mengatur tata usaha, siswa, ketenagaan, sarana, dan prasarana, keuangan (Sabirin, 2012). Sunarto (2011) menjelaskan bahwa kepala sekolah sebagai manajer dituntut memiliki kesiapan untuk mengelola sekolah, kemampuan dan kemauan muncul manakala para pemimpin sekolah dapat membuka diri secara luas untuk menyerap sumber-sumber yang dapat mendorong perubahan manajerial.Untuk melakukan peran dan fungsinya sebagai manajer, kepala sekolah harus memiliki strategi yang tepat untuk:

1) Memberdayakan tenaga kependidikan melalui kerjasama;

2) Memberi kesempatan kepada para tenaga kependidikan untuk meningkatkan profesinya; dan

3) Mendorong keterlibatan seluruh tenaga kependidikan yang menunjang program sekolah.karena jika merujuk pada pandangan manajemen modern, kerjasama merupakan hal yang amat mendasar dalam sebuah organisasi.

c) Kepala sekolah sebagai administrator, kepala sekolah bertanggung jawab atas kelancaran segala pekerjaan dan kegiatan administratif di sekolahnya. Sunarto (2011) memaparkan bahwa kepala sekolah sebagai kategori administrasi pendidikan perlu melengkapi wawasan kepemimpinan pendidikan dengan pengetahuan dan sikap yang antisipatif terhadap perubahan yang terjadi dalam kehidupan masyarakat, termasuk kebijakan 
pendidikan.Sebagai seorang administrator, kepala sekolah harus memiliki kemampuan untuk memperbaiki dan mengembangkan semua fasilitas sekolah. Secara spesifik, kepala sekolah juga dituntut untuk mengelola kurikulum, mengelola administrasi sarana dan prasarana, mengelola administrasi kearsipan, dan mengelola administrasi keuangan (Purwati, 2013). Manajemen keuangan dapat diartikan sebagai tindakan pengurusan keuangan seperti pertanggung jawaban, dan pelaporan (Vivi, 2013).

d) Kepala sekolah sebagai supervisor, supervisi adalah kegiatan mengamati, mengidentifikasi mana hal-hal yang sudah benar, manayang belum benar, dan mana pula yang tidak benar, dengan maksud agar tepat dengan tujuan memberikan pembinaan (Arikunto, 2004; Barinto, 2012; Vivi, 2013).

e) Kepala sekolah sebagai leader, kepemimpinan kepala sekolah merupakan salah satu faktor yang dapat mendorong sekolah dapat mewujudkan visi, misi, tujuan dan sasaran sekolah melalui program-program yang dilaksanakan secara terencana dan bertahap. Karena itu kepemimpinan adalah kegiatan mempengaruhi orang lain agar mau bekerja untuk mencapai tujuan yang telah ditentukan.Untuk kepentingan tersebut, kepala sekolah harus mampu mempengaruhi dan menggerakkan sumber daya sekolah dalam kaitannya dengan perencanaan dan evaluasi program sekolah, pengembangan kurikulum, pembelajaran, pengelolaan ketenagaan, sarana dan sumber belajar, keuangan, pelayanan siswa, hubungan sekolah dengan masyarakat, penciptaan iklim sekolah, dan sebagainya.

f) Kepala sekolah sebagai inovator, dalam rangka melakukan peran dan fungsinya sebagai inovator, kepala sekolah harus memiliki strategi yang tepat untuk menjalin hubungan yang harmonis dengan lingkungan, mencari gagasan baru, mengintegrasikan setiap kegiatan, memberikan teladan kepada seluruh tenaga kependidikan di sekolah dan mengembangkan model-model pembelajaran yang inovatif. Ancok (2012) memaparkan bahwa inovasi adalah suatu perubahan dari sesuatu hal, baik bersifat inkremental maupun perubahan yang bersifat radikal.Peran kepala sekolah sebagai inovator akan tercermin dari cara-cara ia melakukan pekerjaannya 
secara konstruktif, kreatif, delegatif, integratif, rasional dan obyektif, keteladanan, disiplin, serta adaptabel dan fleksibel.

g) Kepala sekolah sebagai motivator, kepala sekolah harus memiliki strategi yang tepat untuk memberikan motivasi kepada para tenaga kependidikan dalam melakukan berbagai tugas dan fungsinya. Karena kepala sekolah meyakini dengan kemampuan membangun motivasi yang baik akan membangun dan meningkatkan efektifitas dan efisiensi kerja (Sabirin, 2012; Purwati, 2013), sehingga bawahannya mampu berkreasi demi mewujudkan mutu pendidikan yang baik pula. Kemampuan kepala sekolah membangun motivasi menjadi salah satu kunci untuk meningkatkan mutu pendidikan karena dikalo-borasikan dengan kinerja guru. Hasil penelitian Septiana, Ngadiman, \& Ivada (2013) menyimpulkan bahwa kepemimpinan kepala sekolah dan motivasi kerja secara bersama-sama berpengaruh signifikan terhadap kinerja guru.

Berdasarkan pemaparan peran kepala sekolah diatas disimpulkan bahwa peranan kepala sekolah sebagai fasilitator, motivator, dan supervisor harus memiliki upaya-upaya tertentu, misalkan:

a) Mengikutsertakan guru-guru dalam setiap kesempatan penataran dan latihan, tanpa melihat sisi kedekatan dan kekeluargaan secara personal dari kepala sekolah;

b) Memberikan dorongan kepada guru untuk melanjutkan pendidikan lebih tinggi, karena kualifikasi guru yang memiliki jenjang pendidikan lebih tinggi tentu akan mempengaruhi mutu pendidikan yang dihadirkan dilingkungan sekolah, dan

c) Membantu guru-guru yang mengalami kesulitan dalam mengelola proses belajar- mengajar.

\section{Langkah -langkah dilakukan oleh kepala MI NU Raudlatut Tholibin dalam} meningkatkan mutu pendidikan

Tugas kepala sekolah sangat kompleks, tidak sekedar mengelola kurikulum dan buku ajar, tapi juga SDM guru, staf tata usaha dan juga mengelola serta mengembangkan aset dan mengelola keuangan institusi. Dengan demikian, dia harus memiliki tiga kecerdasan, yakni kecerdasan profesional, kecerdasan 
personal dan kecerdasan manajerial (Rosyada, 2013). Demikian pula, kepala sekolah harus respek pada para siswanya, termasuk siswa yang tertinggal dalam penguasaan bahan-bahan ajar, agar tidak ada satu anak pun yang tertinggal oleh rombongan belajarnya. Tidak boleh membedakan layanan hanya karena perbedaan etnik, bahasa, budaya dan agama. Kepala sekolah harus memiliki rasa percaya diri untuk berhadapan dengan para pejabat daerah dan pusat, dan tidak boleh superior terhadap guru, staf dan seluruh jajaran pegawai di sekolahnya.

Langkah langkah kepala sekolah di MI NU Raudlatut Tholibin Jepangpakis Jati Kudus dalam meningkatkan manajamen mutu pendidikan dapat dilihat pada gambar alur berikut:

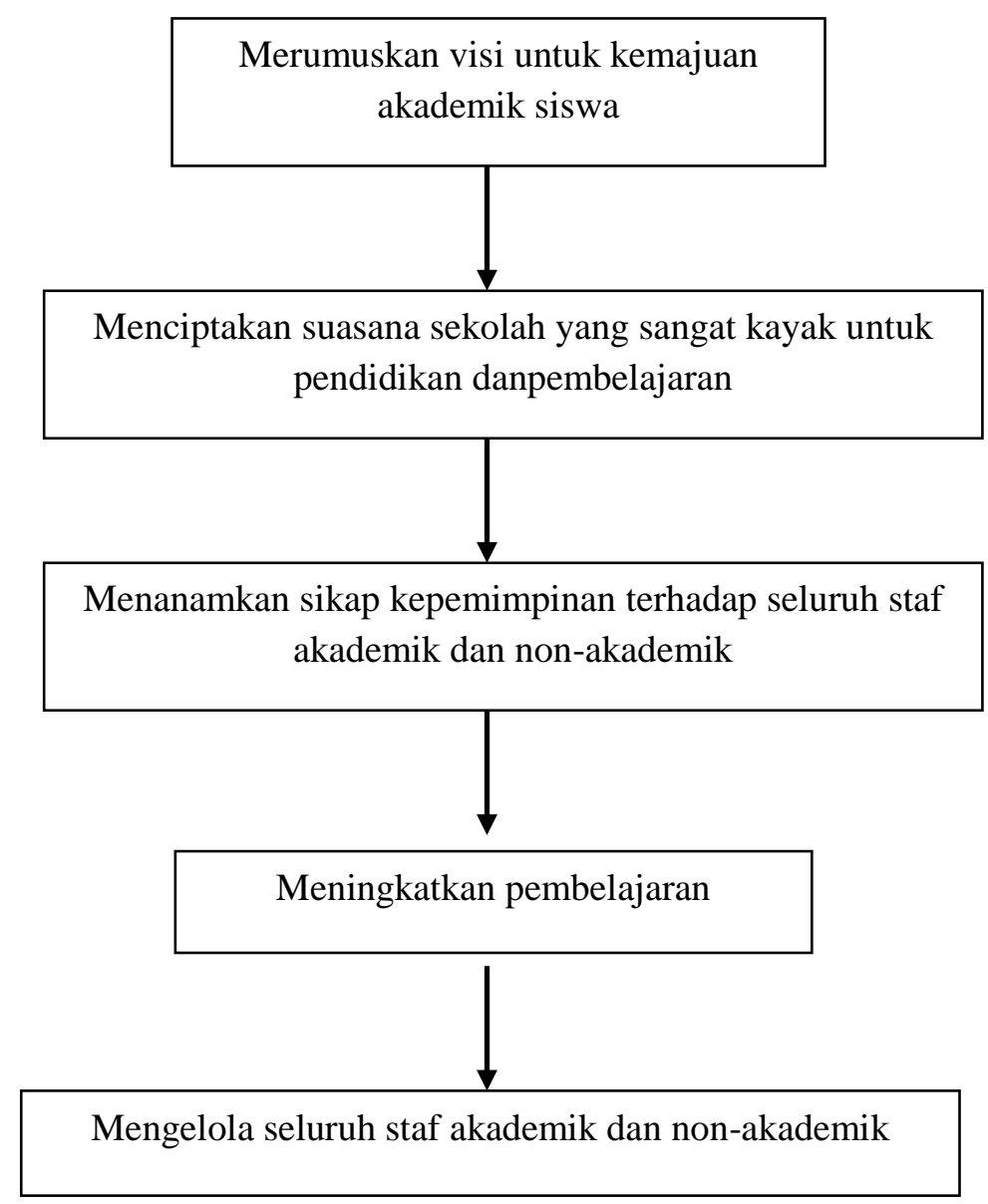

Gambar 2. Diagram langkah langkah Kepala sekolah MI NU 
a) Merumuskan visi untuk kemajuan akademik siswa;

Hasil observasi dalam penelitian ini menunjukkan Kepala sekolah telah merumuskan visi kepemimpinannya yang jelas dan terukur, serta difahami oleh semua staf akademik dan non akademik sehingga mereka memahami apa yang harus dikerjakan sesuai visi kepala sekolahnya.

b) Menciptakan suasana sekolah yang sangat kayak untuk pendidikan dan pembelajaran;

Suasana sekolah yang layak dan kondusif menjadi kunci agar kegiatan pendidikan dan pembelajaran yang dilakukan menjadi lebih baik. Kondisi ini diciptakan dengan berbagai macam cara diantaranya menyusun aturan yang tegas dan lugas untuk guru, tenaga pendidik maupun untuk para siswa. Selain itu kepala sekolah memberikan jaminan keamanan dan kenyamanan untuk para guru serta para tenaga pendidik sehingga mereka dapat fokus untuk bekerja dan menyelesaikan tanggung jawab masing masing.

c) Menanamkan sikap kepemimpinan terhadap seluruh staf akademik dan non-akademik;

Sikap kepemimpinan diberikan melalui pemberian contoh serta teladan yang baik dari kepala sekolah kepada seluruh staf akademik dan non akademik dengan harapan kinerja dari seluruh elemen di sekolah menjadi lebih maksimal. Sikap kepemimpinan yang telah menular kepada para staf juga diharapkan mampu menular kepada para peserta didik yang sekaligus juga dapat menjadi penanaman karakter bagi mereka.

d) Meningkatkan pembelajaran,

Peningkatan pembelajaran dilakukan oleh kepala sekolah melalui berbagai macam upaya yang telah dilakukan seperti: kegiatan diskusi antar guru mata pelajaran, pelatihan serta workshop terkait model dan media pembelajaran, penambahan sarana prasarana media pembelajaran dan juga penyusunan kurikulum plus yang dimiliki oleh madrasah.

e) Mengelola seluruh staf akademik dan non-akademik untuk mengelola proses layanan akademik dan non-akademik dalam rangka mempercepat kemajuan. 
Pengelolaan kepada seluruh staff dilakukan melalui penerapan aturan yang jelas serta adanya reward kepada para staff yang berkinerja baik dan juga punishment kepada para staff yang kurang optimal dalam kinerjanya.

Di samping itu semua, ada hal yang sangat krusial yang harus dilakukan kepala sekolah dalam rangka peningkatan kualitas pendidikan yang menjadi tanggung jawabnya, yakni peningkatan kualitas proses dan hasil belajar. Kunci utama peningkatan mutu tersebut adalah guru. Pendidikan yang baik harus ditopang oleh guru yang memiliki kapabilitas, loyalitas dan integritas, serta akuntabilitas pelaksanaan tugas. Artinya bahwa kepala sekolah harus memiliki komitmen kuat untuk mengembangkan, meningkatkan dan memelihara profesionalisme para guru di sekolahnya dengan cara melaksanakan supervisi secara rutin.

Dan bersamaan dengan itu, kepala sekolah juga terus melakukan analisis terus menerus terhadap kesesuaian hasil belajar siswa dengan visi dan tujuan sekolah, kebutuhan siswa, kebutuhan studi lanjut, serta mengarahkan guru untuk menyesuaikan program pembelajaran dan proses pembelajaran dengan pencapaian visi tersebut, serta dengan berbagai variabel kebutuhan siswa untuk studi lanjut dan bahkan untuk mampu menyesuaikan diri dengan kehdupan sosial kemasyarakatan serta berbagai perubahan yang terjadai sangat cepat dalam kehidupan sosial.

\section{Simpulan}

Berdasarkan pemaparan pada pembahasan, maka dapat disimpulkan bahwa Kepala sekolah di MI NU Raudlatut Tholibin Jepangpakis Jati Kudus telah memiliki kemampuan untuk meningkatkan mutu pendidikan, yang meliputi sebagai edukator, manajer, administrator, supervisor, leader, inovator, dan motivator. Perannya yang sangat kompleks, maka kepala sekolah harus benar-benar melakukan monitoring dan evaluasi terhadap visi misi serta program-program yang terlaksana. Sehingga mampu merumuskan dan menganalisis untuk program-program selanjutnya agar maksimal. Disisi yang lainpun kepala sekolah sebagai pemimpin tertinggi selalu melakukan evaluasi kinerja-kinerja guru, staf, dan lingkungan sekolah guna menarik perhatian masyarakat. 


\section{Daftar Pustaka}

A.R., A., Manarus, R., \& Sidik, H. 1996. Hubungan Supervisi Kepala Sekolah dengan Kepuasan Kerja Guru Sekolah Dasar. Jurnal Ilmu Pendidikan, 3(3)

Ahmad, S. 2013. Faktor Penentu Keberhasilan Kepala Sekolah. Jurnal Penelitian dan Evaluasi Pendidikan, 17(1)

Ancok, Djamaludin. 2012. Psikologi Kepemimpinan dan Inovasi. Jakarta:

Erlangga.

Arikunto, Suharsimi. 2004. Dasar-dasar Supervisi. Jakarta: Rineka Cipta.

Banun Sri, Yusrizal, Usman Nasir. (2016). Strategi Kepala Sekolah Dalam Meningkatkan Mutu Pendidikan pada SMP Negeri 2 Unggul Mesjid Raya Kabupaten Aceh Besar. Jurnal Administrasi Pendidikan Pascasarjana Universitas Syiah Kuala, 4(1)

Barinto. 2012. Hubungan Kompetensi Guru dan Supervisi Akademik Dengan KinerjaGuru SMP Negeri Se-Kecamatan PercutSei Tuan. Jurnal Tabularasa PPS UNIMED. Vol.9 No.2, 201-214.

Busrin, D., Aunurrahman, \& Aswandi. 2014. Supervisi Pengawas Dan Kemampuan Manajerial Kepala Sekolah Dengan Kinerja Guru Smp Negeri Kota Pontianak. Jurnal Pendidikan Dan Pembelajaran, 3(6)

Colby, Jeanette,and Miske Witt. 2000. Defining Quality in Education. Working Paper Of Education Section, Program Division. New York: UNICEF.

Mujtahid. 2011. Pengembangan Profesi Guru. Malang : UIN-Maliki Press.

Mulyasa. 2003. Kurikulum Berbasis Kompetensi. Bandung: Remaja Rosda Karya

Purwanti, Sri. 2013. Peran KepemimpinanKepala Sekolah Dalam EningkatkanDisiplin Kerja Guru Dan Pegawai Di Sma Bakti Sejahtera Kecamatan Kongbeng Kabupaten Kutai Timur. eJournal Administrasi Negara. 1(1), 210-224. 
Rosyada, Dede. 2015. Creative Thinking. Kolom Rector UIN Syarif Hidayatullah Jakarta, Edisi3.118.

Rusmawati, Vivi. 2013. Peran Kepemimpinan Kepala Sekolah Dalam Upaya Meningkatkan Disiplin Kerja Guru Pada SDN 018 Balikpapan. E-Journal Administrasi Negara. 1(2), 395-409.

Sabirin.2012.PerencanaanKepala Sekolah Tentang Pembelajaran. Jurnal Tabularasa PPS Unimed, Volume 9, Nomor 1

Samino, Suwardi. 2014. Kepemimpinan Kepala Sekolah Dalam PengembanganLembaga Pendidikan Islam Kreatif SD Muhammadiyah Kota Madiun. Jurnal Manajemen Pendidikan, 9(2), 186-195.

Saroni, Muhammad 2006. Manajemen Sekolah: Kiat Menjadi Pendidik yang Kompeten. Jogjakarta: Ar-Ruzz

Septiana, R., Ngadiman, \& Ivada, E. 2013. Pengaruh Kepemimpinan Kepala Sekolahdan Motivasi Kerja Terhadap Kinerja Guru SMP Negeri Wonosari. Jupe UNS, 2(1)

Sidi, Indra Djati. 2005. Menuju Masyarakat Belajar. Jakarta : Paramadina

Slamet, PH. 2000. Manajemen Berbasis Sekolah. Jurnal Pendidikan dan Kebudayaan. Jakarta: Departemen Pendidikan Nasional.

Sunarto. 2011. Pengaruh Gaya KepemimpinanKepala Sekolah, Manajemen Berbasis Sekolah dan Iklim Organisasi Terhadap Kepuasan Kerja dan Kinerja Guru SMPdi Wilayah Sub Rayon 04 Kabupaten Demak. Jurnal Analisis Manajemen,5(1), 17-29.

Wahjosumidjo, 2002. Kepemimpinan Kepala Sekolah, Tinjauan Teoritik dan Permasalahannya, Jakarta: PT Raja Grafindo Persada 